\title{
Effects of different lambing season on some reproductive characteristics of ewes and growth performance of lambs in Awassi sheep
}

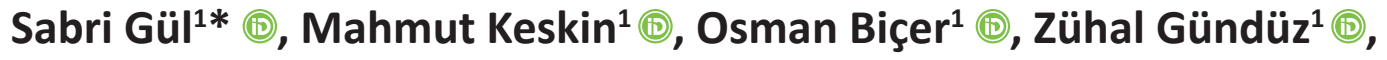 \\ Sedat Behrem² ${ }^{2}$ \\ ${ }^{1}$ Hatay Mustafa Kemal University Agricultural Faculty, Department of Animal Science, Hatay, Turkey \\ ${ }^{2}$ International Centre for Livestock Research and Training, Mamak, Ankara, Turkey
}

\section{Article History \\ Received: 05 June 2020 \\ Accepted: 17 July 2020 \\ *Corresponding Author \\ E-mail: sabrigul@gmail.com}

\section{Key words}

Awassi, birth season, reproductive parameters, growth characteristics

\begin{abstract}
In this study, it was aimed to determine the performance of Awassi sheep and their lambs in different season within the scope of the national breeding project carried out in Gaziantep. For this purpose, a total of 23490 heads of ewes and its lambs reared in different herds and under natural conditions were used in Gaziantep. The study covers the period between 2014 and 2017. The preliminary descriptive statistics showed that $35.24 \%$ and $25.47 \%$ of the ewes gave birth in January and December, respectively. Furthermore, the lamb survival rate at the weaning age was calculated to be $\mathbf{9 7 . 5 4 \%}$ in February and $97.52 \%$ in December. The highest and the lowest birth weights were detected as $4.2 \pm 0.01 \mathrm{~kg}$ and $2.7 \pm 0.09 \mathrm{~kg}$ in January and May, respectively $(P<0.01)$. On the other hand, the highest and lowest mean values for weaning weight ( $60^{\text {th }}$ day live weight) were determined as $21.1 \pm 0.11 \mathrm{~kg}$ and $15.4 \pm 0.45 \mathrm{~kg}$ in lambs respectively born in October and May $(P<0.01)$. As a result, it can be stated that the most appropriate mating period for Awassi sheep reared in Gaziantep province is between August and September considering the reproductive characteristics and lamb growing.
\end{abstract}

\section{Introduction}

Meat production is an important source of animal protein for many people in the world. The increasing human population makes the production of protein mandatory from animal origin. Sheep farming is gaining more importance every day in the production of red meat which is used as an animal-sourced protein in human nutrition and it is considered as an indicator of the development level of countries. The purpose of breeding for meat production in livestock is to produce high quality and heavy carcasses. On the other hand, reproductive performance should also be taken into account for breeding purposes to increase the total amount of meat production. The number of lambs born per ewe, which are used as fattening materials, is closely related to the reproductive performance of the dams. Therefore, it is crucially important to increase the number of lambs born and the survival rate per ewe, if sustainable production capacity is aimed for sheep sourced meat.
Reproductive performance in small ruminants varies depending on the season as well as the other factors such as genetics, age, herd and year $[1,3,4,9,17$, 22]. Although small ruminants usually show seasonal oestrus, it is known that animals of some breeds mate unseasonal or mating periods may take longer than the others $[2,12]$. Births in sheep and goats usually take place in late winter or early spring, which is a time period that pasture conditions are better and the other environmental circumstances are at optimum rates for the growth and development of newborns $[11,12]$.

The high proportion of native sheep breeds are known with low milk yield and litter size in the Turkish sheep population. Insufficient feeding regimes, poor pasture condition and slaughtering of lambs at an early age has led to the reduction of the annual amount of meat produced from sheep Turkey. Moreover, improperly implemented mating programs and practices such as keeping rams in the flock for all year caused significantly increased death rate of newborns [6]. 
Awassi sheep breeding project under farmer's condition has been in progress since 2011 in Gaziantep province, where herd management practices among farmers are approximately similar. This project, as a sub project of "National Sheep and Goat Breeding Project under Farmers Condition", is getting implemented in whole Turkey by Ministry of Agriculture and Forestry via Universities, Research Institutes, Sheep \& Goat Breeder Associations, and breeders actively involved in. The breeders in the project do not apply for any mating program and the rams that are present in the flock throughout the year can mate with females showing oestrus at any time during this period. This practice causes the lambing period to be spread out throughout the year. The increase in mortality, growth retardation and labour loss problems are observed especially in spring births.

There are some studies on the effect of mating season on reproductive characteristics in Awassi sheep, which in practice can be mated in a large period of the year [5]. In this study, Awassi ewes are separated into two groups as three lambing in two years and one lambing per year. In the experiment, it has been reported that the number of lambs born in a year increases by $39.4 \%$ with three lambing in two years. The researchers also stated that both the highest lambing rate and litter size were obtained from the mating of September whereas the mean birth weight was the lowest for this period. Yet in another study, it is shown that the lambs born in winter are higher in birth and weaning weights in Norduz sheep [24]. Gündüz [7] expressed that the average birth and weaning weights for Awassi lambs are 4.4 and 18.5 $\mathrm{kg}$ for those born in the autumn season and $4.0 \mathrm{~kg}$ and $18.5 \mathrm{~kg}$ for those born in the winter season, respectively.

The aim of the study was to determine the total length of mating period and, the reproductive performance of Awassi sheep raised under farm conditions. Additionally, lamb growth and survival characteristics were determined comparatively among different months.

\section{Material and Methods}

The animal material of the study was consisted of 23490 heads of Awassi ewes and their lambs, which were reared in Gaziantep province between 2014 and 2017. In the study, birth records of ewes were taken between these years. The birth and weaning ( $60^{\text {th }}$ day) weights of each lamb were measured by weighing with $50 \mathrm{~g}$ of precision scales. According to the raw data obtained from these records, the births were evaluated for 12 months and the effects of months and seasons on birth and weaning weights of lambs were estimated. The sheep flocks were grazed during daytime in the pasture except for rainy days and they were fed with a mixture of wheat straw, barley, cottonseed and peanut shell as $500 \mathrm{~g} /$ head in the evenings. On the rainy days, $1 \mathrm{~kg} /$ day of straw per animal was added to this mixture as a daily regime. The lambs were allowed to suck their dams twice a day (morning and evening) until being weaned at 60 days of age. These lambs were given concentrate and wheat straw for 15 days and grazed with their mothers in the pasture after 1 month of age. The rams were kept freely in the flocks during the year and allowed to mate with the ewes showing oestrus. After the lambing; birth date, birth weight, sex, birth type and later on the weaning weights of each lamb were recorded. The Chi-Square test was used to compare the effect of months of on reproductive performance. The birth weight and weaning weights of lambs born in different months were compared with one-way ANOVA. All data were processed with the SPSS package program [20].

\section{Results and Discussion}

In the region where the study was carried out, rams are kept in the flocks throughout the year, as a result of the labour routines of the breeders. This situation causes the ewes in oestrus to mate at any time of the year and thus the births to be spread out in different months.

As can be seen from Table 1, the Awassi sheep reared under natural conditions did mostly give birth in December and January $(P<0.05)$. The birth rates in these months averaged for four years, were calculated as $25.47 \%$ and $35.23 \%$, respectively. Considering later highest birth rates, these months were followed by November and February with respectively $15.54 \%$ and $13.04 \%$. In addition, births occurred in the remaining periods of the year; however, these rates were remained extremely low. Additionally, there was no birth in June, July, and August except for 2016, for when only a few ewes gave birth within these months. The relevant fluctuation patterns of the birth rates were strongly similar among those four years. In other words, these findings for the lambing months of the ewes crucially indicate that Awassi ewes were able to mate from April to November under breeders' condition (Figure 1).

Table 1. Birth rates of ewes (\%) per month in different years*

\begin{tabular}{lccccc}
\hline Months & $\mathbf{2 0 1 4}$ & $\mathbf{2 0 1 5}$ & $\mathbf{2 0 1 6}$ & $\mathbf{2 0 1 7}$ & Overall \\
\hline January & 25.19 & 44.30 & 28.43 & 43.05 & 35.23 \\
February & 11.46 & 10.90 & 8.74 & 21.09 & 13.04 \\
March & 0.37 & 0.74 & 1.05 & 0.94 & 0.78 \\
April & 0.17 & 0.46 & 0.43 & 0.16 & 0.31 \\
May & 0.18 & 0.28 & 0.14 & 0 & 0.15 \\
June & 0 & 0 & 0.16 & 0 & 0.04 \\
July & 0 & 0 & 0.12 & 0 & 0.03 \\
August & 0 & 0 & 0.20 & 0 & 0.05 \\
September & 0 & 0.62 & 2.34 & 1.11 & 1.02 \\
October & 7.25 & 7.24 & 17.37 & 1.50 & 8.34 \\
November & 22.15 & 7.87 & 20.99 & 11.13 & 15.54 \\
December & 33.23 & 27.59 & 20.03 & 21.02 & 25.47 \\
P & 0.003 & 0.005 & 0.024 & 0.003 & 0.005 \\
N & 6000 & 6000 & 5740 & 5750 & 23490 \\
\hline
\end{tabular}

*Birth rates were calculated according to the ewe's number in the flocks. 


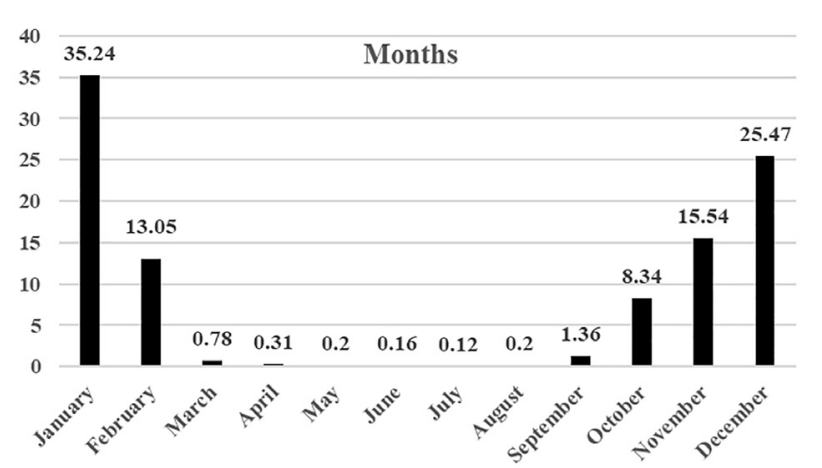

Figure 1. Average birth rate according to months (\%)

The season when the sheep show oestrus behaviours is called a mating season. The length of this period and reproductive performance of sheep are influenced by different factors such as genetic background, age, breed, season, herd management and feeding [1, 3, 4, 9, 17, 22]. As shown in Table 1, the Awassi ewes usually gave birth in December and January $(P<0.05)$. The majority of births $(97.64 \%)$ occurred in the period from October to the end of February. This information states that the sheep of Awassi have started to mate from the late of April and the mating has been largely completed in October. Kaymakçı [12] reported the mating season duration for Awassi sheep as approximately 104.7 days. Our current findings showed that Awassi sheep reared in Gaziantep province have a mating period of around 180 days. Additionally, there are also several studies indicating that the duration of a mating period varies among different breeds. Notter [18] reported the birth rates for Targhee sheep in winter, spring, summer and autumn seasons as $17.18 \%, 81.16 \%, 1.58 \%$, and $0.08 \%$, respectively. In the same study birth rates for Suffolk sheep in the same seasonal order were reported as, 68.59\%, $30.30 \%, 0.18 \%, 0.94 \%$. Yet in another study, Köyceğiz et al. [13] emphasized that the active mating season is between September and October and spring and summer months are anoestrus period for Eastern Anatolia region of Turkey.

Another important concept, as well as birth rate in sheep breeding, is the survival rate. Therefore, in this study, calculated survival rates for the lambs are given in Table 2.

The effect of the birth months on survival rate was statistically significant for each year $(P<0.05)$. It is substantially important to note that there is a problem in terms of the survival rate for the period between March and September.

On the other hand, the survival rate was identified to be in the expected range for December, January, and February, meaning that these months can be accepted as the ideal birth time for Awassi sheep under regional conditions.

As for the birth rate, the effect of birth months on survival rate was also significant for each year $(P<0.05)$.
In the present study, it is noteworthy that there is an interesting problem in terms of survival rate in births between March and September (Table 2). As repeatedly reported by different researchers, sheep can also give birth in off-season. However, survival rate and fertility characteristics are adversely affected in off-season births $[5,10,8,19,16,21]$. In the current study, it is realized that there is a problem in herds in terms of survival rate from March to October, which is a period that is accepted as out of birth season in the region. Susic et al. [21] informed that season had a significant effect on perinatal lamb mortality with an obtained set of values of $1.0 \%$ and $2.0 \%$ for lambs born in autumn and spring, while $11.0 \%$ and $20.0 \%$ during winter and summer, respectively. Variation in the birth weights depending on the season that was identified in the current study may have an effect on the survival status of the lambs. There are also other studies supporting the deduction made by our study $[15,21]$. As well as low birth weight, causes of early lamb losses could be the various number of different factors such as stress, injuries, and starvations. Additionally, some of the reasons may be related to the season, because at different times of the year the ewes and lambs are exposed to different environmental conditions in terms of humidity and temperature. Therefore, the birth season should be taken into account to reduce perinatal lamb deaths [21]

Table 2. Survival rates according to months of birth (\%)

\begin{tabular}{lcccc}
\hline Months & $\mathbf{2 0 1 4}$ & $\mathbf{2 0 1 5}$ & $\mathbf{2 0 1 6}$ & $\mathbf{2 0 1 7}$ \\
\hline January & 96.57 & 95.96 & 94.23 & 99.27 \\
February & 96.63 & 98.07 & 97.96 & 97.48 \\
March & $\mathbf{7 0 . 0 0}$ & 71.43 & 81.36 & 80.00 \\
April & 55.56 & 80.77 & 66.67 & 60.00 \\
May & 60.00 & 37.50 & 50.00 & --- \\
June & --- & --- & 55.56 & --- \\
July & --- & --- & 57.14 & --- \\
August & --- & --- & 63.64 & --- \\
September & --- & 80.00 & 85.50 & 80.56 \\
\hline October & 97.72 & 95.16 & 93.94 & 95.83 \\
\hline November & 97.76 & 94.65 & 98.39 & 85.53 \\
\hline December & 94.46 & 98.03 & 98.04 & 99.55 \\
P & 0.003 & 0.005 & 0.024 & 0.003 \\
\hline
\end{tabular}

Birth weights of lambs born in different months are given in Table 3. As shown in Table 3, the highest birth weights were obtained in January and February for 2016 and 2017, and in October for 2014 and 2015. As the average of all years, the highest and the lowest values for birth weights were $4.2 \pm 0.01 \mathrm{~kg}$ and $2.7 \pm 0.09 \mathrm{~kg}$ in January and May births, respectively $(P<0.01)$.

The results for weights of the lambs on the $60^{\text {th }}$ day are presented in Table 4. Regarding the Table 4, the highest mean live weights of $60^{\text {th }}$ days were found to be for the lambs born in January and February for 2016 and 2017 and for the lambs born in October for 2014 and 2015. 
Table 3. Birth weights of lambs born in different months

\begin{tabular}{|c|c|c|c|c|c|c|c|c|c|}
\hline Months & $\mathbf{n}$ & 2014 & $\mathbf{n}$ & 2015 & $\mathbf{n}$ & 2016 & $\mathbf{n}$ & 2017 & Overall \\
\hline January & 1369 & $4.2 \pm 0.02^{c d}$ & 2527 & $4.2 \pm 0.02^{\mathrm{de}}$ & 1502 & $4.3 \pm 0.02^{d}$ & 2755 & $4.0 \pm 0.02^{d}$ & $4.2 \pm 0.01^{c}$ \\
\hline February & 623 & $4.1 \pm 0.03^{c d}$ & 623 & $4.0 \pm 0.04^{\mathrm{de}}$ & 490 & $4.1 \pm 0.04^{d}$ & 1350 & $4.2 \pm 0.03^{d}$ & $4.1 \pm 0.02^{c}$ \\
\hline March & 20 & $3.7 \pm 0.15^{b c}$ & 42 & $3.4 \pm 0.05^{b}$ & 59 & $3.4 \pm 0.07^{a b c}$ & 60 & $3.6 \pm 0.11^{c}$ & $3.5 \pm 0.05^{b}$ \\
\hline April & 9 & $3.5 \pm 0.19^{b}$ & 26 & $3.4 \pm 0.07^{b}$ & 24 & $3.3 \pm 0.17^{\mathrm{ab}}$ & 10 & $2.1 \pm 0.20^{\mathrm{a}}$ & $3.2 \pm 0.09^{\mathrm{ab}}$ \\
\hline May & 10 & $2.8 \pm 0.14^{a}$ & 16 & $2.6 \pm 0.13^{a}$ & 8 & $3.0 \pm 0.02^{\mathrm{a}}$ & --- & --- & $2.7 \pm 0.09^{a}$ \\
\hline June & --- & --- & --- & --- & 9 & $3.3 \pm 0.19^{a b}$ & --- & --- & $3.3 \pm 0.19^{b}$ \\
\hline July & --- & --- & --- & --- & 7 & $3.4 \pm 0.16^{\mathrm{abc}}$ & --- & --- & $3.4 \pm 0.16^{b}$ \\
\hline August & --- & --- & --- & --- & 11 & $3.4 \pm 0.08^{\mathrm{ab}}$ & --- & --- & $3.4 \pm 0.08^{b}$ \\
\hline September & --- & --- & 35 & $3.7 \pm 0.13 b^{c}$ & 131 & $3.9 \pm 0.08^{\mathrm{bcd}}$ & 71 & $3.3 \pm 0.04^{b}$ & $3.7 \pm 0.05^{b c}$ \\
\hline October & 394 & $4.4 \pm 0.06^{d}$ & 413 & $4.3 \pm 0.05^{\mathrm{e}}$ & 974 & $4.0 \pm 0.03^{c d}$ & 96 & $4.0 \pm 0.08^{d}$ & $4.1 \pm 0.02^{c}$ \\
\hline November & 1204 & $4.1 \pm 0.03^{c d}$ & 448 & $3.9 \pm 0.04^{\mathrm{cd}}$ & 1177 & $4.0 \pm 0.02^{\mathrm{cd}}$ & 712 & $3.9 \pm 0.03^{c d}$ & $4.0 \pm 0.01^{c}$ \\
\hline December & 1806 & $4.1 \pm 0.02^{\mathrm{cd}}$ & 1574 & $4.1 \pm 0.02^{\text {de }}$ & 1122 & $4.2 \pm 0.03^{d}$ & 1345 & $3.9 \pm 0.02^{c d}$ & $4.1 \pm 0.01^{c}$ \\
\hline$P$ & & 0.001 & & 0.001 & & 0.001 & & 0.001 & 0.001 \\
\hline Total & 5435 & $4.1 \pm 0.01$ & 5704 & $4.0 \pm 0.01$ & 5514 & $4.1 \pm 0.01$ & 6399 & $4.0 \pm 0.01$ & $4.1 \pm 0.01$ \\
\hline
\end{tabular}

*Letters in the same column show differences; $\left(\overline{\mathrm{x}} \pm \mathrm{S}_{\overline{\mathrm{x}}}, \mathrm{kg}\right)$

When all four years were averaged for this trait, the highest and the lowest values were obtained in October with $21.1 \pm 0.11 \mathrm{~kg}$ and in May with $15.4 \pm 0.45 \mathrm{~kg}$ $(P<0.01)$, respectively.

In this study, it was identified that birth and weaning weights were affected by the month of birth for each of the three years (Table 3 and Table 4). Lambs born between March and September had lower values for both birth weight and weaning weight than those born in the other months. We know that both birth weight and reproductive performance are also affected by environmental factors and breed differences due to their quantitative nature $[8,9,13,14,22,24]$. It can be said that the reason for the birth weight decrease from February to May in lambs is due to the recent malnutrition of the mothers. Because, in the last third of the pregnancy which is the best time for the development of offspring, the pastures may be inadequate for grazing. Yılmaz et al. [24] reported that Norduz lambs born in the winter season were heavier than those born in the spring period. On the other hand, Boujenane [1] stated that the birth and weaning weights in D'man sheep were affected by season and that the lambs born in spring had lower live weight than lambs born in the summer period. In the same study, weaning weights were reported as $25.1 \mathrm{~kg}$ for the February-March periods, $21.8 \mathrm{~kg}$ for the JuneJuly and $22.1 \mathrm{~kg}$ in October-November periods. Freaking et al. [4] found that birth weights in lambs born in October and December were higher than those born in August. The mean birth weight was reported as $4.2 \mathrm{~kg}$ by Üstüner and Oğan [23], 60 ${ }^{\text {th }}$ day weight was reported as $17.34 \mathrm{~kg}$ following the same study and found as $11.53 \mathrm{~kg}$ by [14] for Awassi lambs. It can be said that the birth and weaning weights found by our present study are quite similar to the results of these studies mentioned above, also considering the differences in climate and management-feeding between regions. Since sheep breeding is usually carried out under semi-intensive conditions, nutritional problems especially arising from roughage supplying occur in the summer period. The negative effect of this situation on milk yield and high environmental temperature rates adversely affects the development of lambs during the late spring and summer season.

Table 4. Weaning weights of lambs according to the month of birth

\begin{tabular}{lccccccccc}
\hline Months & $\mathbf{n}$ & $\mathbf{2 0 1 4}$ & $\mathbf{n}$ & $\mathbf{2 0 1 5}$ & $\mathbf{n}$ & $\mathbf{2 0 1 6}$ & $\mathbf{n}$ & $\mathbf{2 0 1 7}$ & Overall \\
\hline January & 1322 & $18.9 \pm 0.09^{\mathrm{abc}}$ & 2422 & $18.0 \pm 0.08^{\text {cd }}$ & 1494 & $21.8 \pm 0.10^{\mathrm{f}}$ & 2736 & $19.1 \pm 0.07^{\mathrm{b}}$ & $19.2 \pm 0.04^{\mathrm{bc}}$ \\
February & 601 & $19.3 \pm 0.16^{\mathrm{bc}}$ & 595 & $18.0 \pm 0.16^{\mathrm{cd}}$ & 488 & $21.6 \pm 0.15^{\mathrm{ef}}$ & 1316 & $20.2 \pm 0.10^{\mathrm{b}}$ & $19.8 \pm 0.07^{\mathrm{bc}}$ \\
March & 14 & $16.9 \pm 0.44^{\mathrm{ab}}$ & 29 & $17.0 \pm 0.61 \mathrm{~b}^{\mathrm{c}}$ & 48 & $16.5 \pm 0.33^{\mathrm{ab}}$ & 48 & $18.6 \pm 0.39^{\mathrm{b}}$ & $17.4 \pm 0.23^{\mathrm{ab}}$ \\
April & 5 & $16.8 \pm 0.32^{\mathrm{ab}}$ & 21 & $15.8 \pm 0.34^{\mathrm{b}}$ & 16 & $14.8 \pm 0.52^{\mathrm{a}}$ & 6 & $16.2 \pm 0.91^{\mathrm{a}}$ & $15.6 \pm 0.27^{\mathrm{a}}$ \\
May & 6 & $16.5 \pm 0.34^{\mathrm{a}}$ & 6 & $13.8 \pm 0.47^{\mathrm{a}}$ & 4 & $16.7 \pm 0.74^{\mathrm{ab}}$ & --- & --- & $15.4 \pm 0.45^{\mathrm{a}}$ \\
June & --- & --- & --- & --- & 5 & $17.0 \pm 1.02^{\mathrm{abc}}$ & --- & --- & $17.0 \pm 1.02^{\mathrm{ab}}$ \\
July & --- & --- & --- & --- & 4 & $17.6 \pm 0.35^{\text {abcd }}$ & --- & --- & $17.6 \pm 0.35^{\mathrm{ab}}$ \\
August & --- & --- & --- & --- & 7 & $18.4 \pm 0.27^{\text {bcde }}$ & --- & --- & $18.4 \pm 0.27^{\text {abc }}$ \\
September & --- & --- & 28 & $15.9 \pm 0.28^{\mathrm{b}}$ & 112 & $20.1 \pm 0.46^{\text {cdef }}$ & 57 & $15.4 \pm 0.21^{\mathrm{a}}$ & $18.2 \pm 0.32^{\mathrm{abc}}$ \\
October & 385 & $21.1 \pm 0.16^{\mathrm{b}}$ & 396 & $22.2 \pm 0.22^{\mathrm{e}}$ & 915 & $20.6 \pm 0.15^{\text {def }}$ & 91 & $20.5 \pm 0.63^{\mathrm{b}}$ & $21.1 \pm 0.11^{\mathrm{c}}$ \\
November & 1176 & $19.4 \pm 0.12^{\mathrm{bc}}$ & 424 & $19.3 \pm 0.19^{\mathrm{d}}$ & 1158 & $20.5 \pm 0.11^{\text {def }}$ & 69 & $19.5 \pm 0.17^{\mathrm{b}}$ & $19.8 \pm 0.07^{\mathrm{bc}}$ \\
December & 1705 & $18.8 \pm 0.09^{\mathrm{abc}}$ & 1544 & $18.0 \pm 0.08^{\mathrm{cd}}$ & 1101 & $22.3 \pm 0.12^{\mathrm{f}}$ & 1339 & $19.1 \pm 0.10^{\mathrm{b}}$ & $19.3 \pm 0.05^{\mathrm{bc}}$ \\
P & & 0.000 & & 0.000 & & 0.000 & & 0.000 & 0.000 \\
Total & $\mathbf{5 2 1 4}$ & $\mathbf{1 9 . 2 \pm 0 . 0 5}$ & $\mathbf{5 4 6 5}$ & $\mathbf{1 8 . 4 \pm 0 . 0 5}$ & $\mathbf{5 3 5 2}$ & $\mathbf{2 1 . 3 \pm 0 . 0 5}$ & $\mathbf{6 2 9 2}$ & $\mathbf{1 9 . 3 \pm 0 . 0 5}$ & $\mathbf{1 9 . 5 \pm 0 . 0 3}$ \\
\hline
\end{tabular}

*Letters in the same column show differences; $\left(\bar{x} \pm S_{\bar{x}}, k g\right)$ 


\section{Conclusion}

The main purpose of livestock production is to increase the profitability of each animal as much as possible. Therefore, to provide the desired level of profitability, lamb losses should be minimized and environmental factors should be optimized. The results have shown that season significantly influenced the birth weight, weaning weight and litter size. The mentioned factors can be influenced by pasture (as a food source) feeding regime, mating time and climate characteristics. With good herd management practices, off-season lamb losses will be prevented and boost profitability will increase. This study showed that Awassi sheep could ideally mate from May to the end of October. In conclusion, it can be said that it is an advantage if being taken into account in the application of accelerated lambing systems due to these properties of the sheep. Also, milk production from the Awassi sheep may be spread over a longer period.

\section{Declaration of competing interest}

The authors declare that there is no conflict of interest regarding the publication of this article.

\section{Acknowledgments}

In this study, the authors thank the Research Foundation of Hatay Mustafa Kemal University for its financial supports (Project No: 13981). Also, all data used in the study were from a project named "Improvement of Awassi Sheep under Farm Conditions" supported by the Ministry of Agriculture and Forestry of the Republic of Turkey.

\section{References}

1. Boujenane I (2012). Comparison of purebred and crossbred D'man ewes and their terminal-sired progeny under accelerated lambing. Small Ruminant Res 106: 41-46.

2. Boztepe S (2015). Koyun Yetiştiriciliği. (Selçuk Üniversitesi Basımevi 1. Baskı, Selçuklu- Konya).

3. Esen F, Bozkurt T (2001). Akkaraman ırkı koyunlarda flushing ve östrus senkronizasyonu uygulamasının döl verimi üzerine etkisi. Turk J Vet Anim Sci 25: 365-368.

4. Freaking BA, Leymaster KA, Young LD (2000). Evaluation of Dorset, Finnsheep, Romanov, Texel and Montadale breeds of sheep: I. Effects of ram breed on productivity of ewes of two crossbred populations. Journal of Anim Sci 78: 1422-1429.

5. Gül S, Keskin M (2010). Reproductive characteristics of Awassi ewes under Cornell Alternate Month Accelerated Lambing System. Ital J Anim Sci 9: 255-259.

6. Gül S, Örnek H (2018). Gaziantep ilinde küçükbaş hayvan yetiştiriciliğinin yapısal özellikleri: I. Koyun Yetiştiriciliği. Mustafa Kemal Üniversitesi Ziraat Fakültesi Dergisi, 23: 307-315.

7. Gündüz Z (2014). Kilis Koşullarında Geleneksel Koyun Yetiştiriciliği Sistemi İçerisinde Farklı Dönemlerde Doğan İvesi Erkek ve Dişi Kuzuların Gelişme ve Besi Performansı. Mustafa
Kemal Üniversitesi Fen Bilimleri Enstitüsü Zootekni Anabilim Dalı, Yüksek Lisans Tezi, 49 sy.

8. Hamadeh SK, Barbour EK, Abi Said M, Daada K (1996). Reproductive performance of postpartum Awassi ewes under different lambing regimes. Small Ruminant Res 19: 149-154.

9. Hansen C, Shrestha JNB (2002). Consistency of genetic parameters of productivity for ewes lambing in February, June and October under an 8 month breeding management. Small Ruminant Res 44: 1-8.

10. Jenkinson CMC, Peterson SW, Mackenzie DDS, McDonald MF, McCutcheon SN (1995). Seasonal effects on birth weight in sheep are associated with changes in placental development. New Zeal J Agr Res 38: 337-345.

11. Kaymakçı M (2006). Keçi Yetiştiriciliği. (Meta Basım Matbaacılık Hizmetleri, Bornova, İzmir).

12. Kaymakçı M (2010). İleri Koyun Yetiştiriciliği. (Meta Basım Matbaacılık Hizmetleri, Bornova, İzmir).

13. Köyceğiz F, Emsen E, Diaz CAG, Kutluca M (2009). Effects of lambing season, lamb breed and ewe parity on production traits of fat tailed sheep and their lambs. J Anim Vet Adv 8: 195-198.

14. Kul S, Akcan A (2002). İvesi ve Ost-Friz x İvesi melez $\left(F_{1}\right)$ kuzularda büyüme, yaşama gücü ve bazı vücut ölçüleri. Uludag Uni J Fac Vet Med 21: 109-114.

15. Maud BA, Duffell SJ (1977). Lamb mortality in relation to prolificacy. Anim Prod 24: 158-159.

16. Mohammed SA, Razzaque MA (2016). Lifetime reproductive and lamb crop yields of fat-tailed Naeemi and imported border Leicester Merino ewes in intensive system of production. Small Ruminant Res 144: 269-275.

17. Molik E, Misztal T, Romanowicz K, Weierzchos E (2007). Dependence of the lactation duration and efficiency on the season of lambing in relation to the prolactin and melatonin secretion in ewes. Livest Sci 107: 220-226.

18. Notter DR (2000). Effects of ewe age and season of lambing on prolificacy in us Targhee, Suffolk and Polypay sheep. Small Ruminant Res 38: 1-7.

19. Rosa HJD, Bryant MJ (2003). Seasonality of reproduction in sheep. Small Ruminant Res 48: 155-171.

20. SPSS (2013). IBM SPSS Statistics 21.0 for Windows. Armonk, NY.

21. Susic V, Pavic V, Mioc B, Stokovic I, Kabalin AE (2005). Seasonal variations in lamb birth weight and mortality. Veterinarski Arhiv 75: 375-381.

22. Şireli HD, Vural ME, Karataş A, Akça N, Koncagül S, Tekel N (2015). Birth and weaning weights of Awassi lambs raised in the GAP International Agricultural Research and Training Center. Ankara Üni Vet Fak Derg 62: 139-145.

23. Üstüner H, Oğan MM (2013). Main productive performance of Awassi Sheep in the central Anatolian region of Turkey. Turk J Vet Anim Sci 37: 271-276.

24. Yılmaz O, Denk H, Bayram D (2007). Effects of lambing season, sex and birth type on growth performance in Norduz lambs. Small Ruminant Res 68: 336-339. 